\title{
PENGARUH CORPORATE GOVERNANCE TERHADAP PENGUNGKAPAN PENGENDALIAN INTERNAL PADA PERUSAHAAN PERBANKAN YANG TERDAFTAR DI BURSA EFEK INDONESIA TAHUN 2013-2015
}

\author{
Stefany \\ Universitas Tarumanagara \\ stefanylibra3@gmail.com \\ Henryanto Wijaya \\ Universitas Tarumanagara \\ henryanto.wijaya@gmail.com
}

\begin{abstract}
The purpose of this research was to obtain and analyze empirical evidence about the effect of corporate governance (board size, independent commissioner, managerial ownership, institutional ownership, audit committee size, and audit committee education) on internal control disclosure. Research carried out on 30 banking companies listed on the Indonesia stock exchange (BEI) in the period 2013 - 2015. The statistical method used to test the hypothesis of the research is a multiple linear regression model. Therefore, before testing the hypothesis, a number of classic assumption test need to be conducted first. With a 95\% confidence level, research shows that board size, managerial ownership, and audit committee size have a significant influence on internal control disclosure, while independent commissioner, institutional ownership, and audit committee size not have a significant effect on internal control disclosure. Should further research can increase the population of companies other than the banking companies and can add independent variables.
\end{abstract}

Keywords : internal control disclosure, board size, independent commissioner, managerial ownership, institutional ownership, audit committee size, audit committee education

\section{PENDAHULUAN}

Dengan adanya skandal yang dilakukan oleh perusahaan besar dan KAP tersebut, mendorong disahkannya Sarbanes-Oxley Act pada tahun 2002 (Zhang, J. Zhou dan N. Zhou, 2007). Tujuannya adalah untuk mengatasi kecemasan yang meningkat dari investor tentang integritas pelaporan keuangan perusahaan. Salah satu aspek penting dari SOX adalah terdapat dua bagian khusus berfokus pada isu - isu pengendalian internal terkait dengan pelaporan keuangan. Penerapan dan pengungkapan pengendalian internal pada perusahaan perbankan di Indonesia merupakan pengungkapan wajib (mandatory disclosure) yang diatur dalam Peraturan Bank Indonesia nomor 11/25/2009 tentang Penerapan Manajemen Risiko Bagi Bank Umum, yang dijabarkan lebih lanjut dalam Surat Edaran Bank Indonesia nomor 5/22/DPNP tahun 2003 mengenai pedoman standar sistem pengendalian internal bagi bank umum, sehingga perusahaan perbankan wajib menerapkan pengendalian internal dalam 
kegiatan operasinya dan mengungkapkan pengendalian internal secara menyeluruh.

Ketentuan pengungkapan pengendalian internal pun diperkuat oleh adanya Peraturan Bank Indonesia nomor 14/14/PBI/2012 tentang Transparansi dan Publikasi Laporan Bank yang dijabarkan lebih lanjut dalam Surat Edaran Bank Indonesia nomor 14/35/DPNP tahun 2012 tentang Laporan Tahunan Bank Umum dan laporan Tahunan Tertentu yang Disampaikan kepada Bank Indonesia. Kasus skandal laporan keuangan ganda Bank Lippo menjadi salah satu contoh keengganan perbankan untuk mengungkapkan berapa besar laba sesungguhnya yang diperoleh perusahaan. Beberapa kasus lain yaitu kasus L/C (letter of credit) fiktif Bank BNI tahun 2003, kasus pembekuan usaha Bank Global pada tahun 2004, kasus Bank Century tahun 2008, dan masih banyak kasus bank bermasalah lainnya yang membuktikan kurangnya penerapan prinsip corporate governance pada perbankan di Indonesia Kurangnya transparansi yang dilakukan pihak manajemen bank kepada stakeholder, merupakan salah satu penyebab utama maraknya kasus bank bermasalah yang terjadi di Indonesia. Penyebab lainnya, yaitu tugas dan tanggung jawab dewan komisaris selaku pengawas pelaksanaan corporate governance pada perbankan belum dilaksanakan dengan baik (http://www.tempointeraktif.com 2009). Industri perbankan merupakan industri yang berbasis kepercayaan, maka dari itu perbankan harus menerapkan prinsip Corporate Governance dengan baik. Dengan menerapkan Corporate Governance, perusahaan sudah menerapkan prinsip transparansi yang lebih luas kepada publik. Penerapan Corporate Governance pada perusahaan diharapkan dapat meningkatkan pengawasan terhadap manajemen untuk mendorong pengambilan keputusan yang efektif, mencegah tindakan oportunistik yang tidak sejalan dengan tujuan serta sasaran perusahaan, dan mengurangi asimetri informasi antara pihak eksekutif dan para stakeholder perusahaan.

\section{TELAAH LITERATUR}

Shuguang Zhou and Lirong Chen (2010) meneliti 1557 perusahaan non-keuangan yang terdaftar pada SZSE dan SSE tahun 2008, menunjukkan bahwa corporate governance adalah salah satu faktor penting yang mempengaruhi kualitas pengungkapan. Pengungkapan pengendalian internal berpengaruh positif terhadap ukuran dewan komisaris, proporsi dewan komisaris independen, dan komite audit. Penelitian yang dilakukan oleh Leng dan Ding (2011) menunjukkan hubungan yang positif antara pengungkapan pengendalian internal dengan dewan 
komisaris, rangkap jabatan ketua dan manajer umum, tingkat pendidikan komisaris, dan tingkat pendidikan komite audit.

Berdasarkan uraian diatas, maka industri perbankan perlu menerapkan prinsip Corporate Governance dan mengungkapkan pengendalian internal agar dapat meningkatkan kepercayaan investor dan stakeholder lainnya. Mengingat luasnya ruang lingkup dalam penelitian,serta untuk menghindari tidak terarahnya penelitian ini, maka dalam penelitian ini dibatasi pada variabel independen (corporate governance) yang dipresentasikan oleh struktur kepemilikan, ukuran dewan komisaris, komposisi dewan komisaris independen, ukuran komite audit, dan latar belakang pendidikan akuntansi atau keuangan komite audit. Struktur kepemilikan dibagi menjadi yaitu kepemilikan manajerial dan kepemilikan institusional. Untuk variabel dependen yang akan dibahas yaitu pengungkapan pengendalian internal. Penelitian ini akan dilakukan pada perusahaan perbankan yang terdaftar di BEI pada tahun 2013 2015. Adapun tujuan penelitian ini secara garis besar adalah untuk menguji dan menganalisis pengaruh mekanisme Corporate Governance terhadap pengungkapan pengendalian internal pada industri perbankan yang terdaftar di BEI pada tahun 2013-2015.

Sedangkan manfaat dari penelitian ini diharapkan dapat memberikan informasi mengenai pengaruh mekanisme corporate governance terhadap pengungkapan pengendalian internal pada perusahaan di Indonesia khususnya perusahaan perbankan. Penelitian ini juga diharapkan dapat menambah pengetahuan mengenai pengungkapan pengendalian internal yang bersifat wajib bagi perusahaan perbankan di Indonesia. Pengendalian internal menjadi hal yang utama perusahaan terutama setelah adanya Sarbanes-Oxley Act pada tahun 2002. Sarbanes-Oxley Act (SOX) mendorong banyak perusahaan untuk lebih memperhatikan aspek governance termasuk peningkatan bagi fee bagi proses auditing dan pengendalian internal (Griffin et al, 2008). Definisi pengendalian internal dalam standar Profesi Akuntansi Publik pada SA 319 paragraf 2, pengendalian intern adalah suatu proses yang dijalankan oleh dewan komisaris,manajemen ,dan personel entitas lain yang didesain untuk memberikan keyakinan memadai tentang pencapaian tiga golongan tujuan berikut ini: (a) keandalan pelaporan keuangan, (b) efektivitas dan efisiensi operasi dan (c) kepatuhan terhadap hukum dan peraturan yang berlaku. 
COSO (2013) mendefinisikan pengendalian internal yaitu, Internal control is a process, affected by an entity's board of directors, management, and other personnel, management, and other personnel, designed to provide reasonable assurance regarding the achievement of objectives relating to operations, reporting, and compliance. Dari pengertian pengendalian internal yang diuraikan diatas membuktikan bahwa pengungkapan pengendalian internal perusahaan sangat mempengaruhi penilaian terhadap perusahaan. Di negara-negara yang telah mewajibkan disclosure atas pengendalian intern maupun tata kelola perusahaan, pengungkapan di laporan tahunan perusahaan merupakan kewajiban, bukan hanya meningkatkan penilaian perusahaan. Di negara-negara yang belum mewajiban pengungkapan pengendalian internal, pengungkapan akan memberikan nilai tambah bagi perusahaan. Penilaian terhadap perusahaan dari publik dan dari investor, terkait kondisi sistem informasi akuntansi, pengendalian intern, pengelolaan risiko dan tata kelola perusahaan mempengaruhi keputusan manajemen atau dewan komisaris terkait dengan pengungkapan dalam laporan tahunan perusahaan. Menurut Linda dan Febrianty (2010), corporate governance adalah seperangkat tata hubungan di antara manajemen, direksi, dewan komisaris, pemegang saham dan para pemangku kepentingan (stakeholder) lainnya yang mengatur dan mengarahkan kegiatan perusahaan. Corporate governance memiliki 5 asas, antara lain akuntabilitas, transparansi, responsibilitas, independensi dan fairness. Menurut Forum for Corporate Governance in Indonesia (2012) dalam publikasinya dengan menerapkan corporate governance, ada beberapa manfaat yang dapat diperoleh, antara lain : (i) Mudah untuk meningkatkan modal, (ii) Menurunkan biaya modal, (iii) Meningkatkan kinerja bisnis dan peningkatan kinerja ekonomi, dan (iv) Berdampak baik pada harga saham. Corporate Governance yang digunakan dalam penelitian ini dipresentasikan dengan ukuran dewan komisaris, komposisi dewan komisaris independen, kepemilikan manajerial, kepemilikan institusinal, ukuran komite audit, dan latar belakang pendidikan akuntansi atau keuangan komite audit. Dewan komisaris memegang peranan penting dalam pelaksanaan corporate governance. Tugas dari dewan komisaris adalah untuk melakukan pengawasan terhadap kinerja manajemen dan bertindak untuk memberikan masukan kepada dewan direksi dan memberikan jaminan transparansi yang dilakukan oleh manajemen. Dewan komisaris juga 
diberikan wewenang untuk mengambil keputusan atas nama pemilik (Patelli dan Prencilpe, 2007 dalam Achmad, 2012:2). Namun, pengambilan keputusan yang dilakukan dewan komisaris hanya dalam lingkup fungsinya sebagai pengawas, sehingga keputusan mengenai kegiatan operasional perusahaan tetap menjadi tanggung jawab dewan direksi. termasuk dalam kategori terafiliasi (Komite Nasional Kebijakan Governance, 2006:13). Dalam penelitian ini total dewan komisaris yang terdapat pada perusahaan perbankan dijadikan sebagai proksi ukuran dewan komisaris. Dewan komisaris independen dalam struktur organisasi perusahaan beranggotakan dewan komisaris yang berasal dari luar perusahaan berfungsi untuk menyeimbangkan dalam pengambilan keputusan khususnya dalam rangka perlindungan terhadap pemegang saham minoritas dan pihak-pihak lain yang terkait (Juniarti dan Sentosa, 2009:90). Pengukuran dewan komisaris independen dalam penelitian ini adalah dengan cara menjumlah semua anggota dewan komisaris independen yang berasal dari luar perusahaan dibagi dengan semua anggota dewan komisaris yang terdapat pada perusahaan tersebut.

Kepemilikan manajerial merupakan perwujudan dari prinsip transparansi dari
GCG. Dalam mengelola perusahaan manajemen harus transparan agar tidak terjadi konflik kepentingan dengan para pemegang saham sebagai pemilik. Mehran (1992) mengartikan kepemilikan manajerial sebagai proporsi saham biasa yang dimiliki oleh manajemen. Manajer yang memiliki saham perusahaan tentunya akan menselaraskan kepentingannnya dengan kepentingan sebagai pemegang saham. Hal ini menunjukkan bahwa kepemilikan manajerial sejalan dengan agency theory. Sementara manajer yang tidak memiliki saham perusahaan, ada kemungkinan hanya mementingkan kepentingannya sendiri sehingga dapat timbul masalah agency. Kepemilikan manajerial adalah jumlah kepemilikan saham yang dimiliki oleh pihak manajemen dari seluruh modal saham perusahaan yang dikelola (Gideon 2005). Dalam penelitian ini, kepemilikan manajerial diukur dengan cara menjumlahkan lembar saham yang dimiliki oleh dewan komisaris dan direksi pada perusahaan tersebut kemudian dibagi dengan jumlah lembar saham yang beredar pada perusahaan tersebut dan hasilnya akan dipersentasekan. Kepemilikan institusional merupakan persentase kepemilikan saham perusahaan yang dimiliki oleh investor institusional seperti pemerintah, perusahaan investasi, bank, 
perusahaan asuransi maupun kepemilikan lembaga dan perusahaan lain. Investor institusional diyakini memiliki kemampuan untuk memonitor tindakan manajemen lebih baik dibandingkan dengan investor individual, dimana investor institusional tidak akan mudah diperdaya dengan tindakan manipulasi yang dilakukan oleh manajemen (Rachmawati dan Triatmoko 2007). Kepemilikan institusional memiliki fungsi pengawasan terhadap perilaku manajemen dalam upaya meminimalisir masalahmasalah agensi yang mungkin akan timbul. Fidyati (2004) menjelaskan bahwa investor institusional menghabiskan lebih banyak waktu untuk melakukan analisis investasi dan mereka memiliki akses atas informasi yang terlalu mahal perolehannya bagi investor lain. Kepemilikan institusional dalam penelitian ini diukur dengan cara menjumlahkan lembar saham yang dimiliki oleh pihak institusi seperti perusahaan, lembaga keuangan, perusahaan investasi dan koperasi tersebut kemudian dibagi dengan jumlah lembar saham yang beredar pada perusahaan tersebut dan hasilnya akan dipersentasekan.

Komite Audit memiliki peranan yang penting dalam mengawasi berbagai aspek organisasi. Tugas utama komite audit termasuk pemeriksaan dan pengawasan tentang proses pelaporan keuangan dan kontrol internal. Demikian juga fungsi dari komite audit termasuk didalamnya adalah meningkatkan kepercayaan publik terhadap kelayakan dan objektifitas laporan keuangan serta meningkatkan kepercayaan terhadap adanya kontrol internal yang lebih baik. Dalam pelaksanaan fungsinya agar maksimal, komite audit menjalankan aktivitasnya dengan mengadakan rapat. Total komite audit yang terdapat pada perusahaan perbankan dijadikan sebagai proksi ukuran komite audit dalam penelitian ini. Anggota komite audit harus mampu dan mengerti serta menganalisa laporan keuangan. Kompetensi komite audit diwujudkan oleh keahlian keuangan yang dimiliki anggota komite. Berdasarkan Keputusan Ketua Bapepam No. Kep-29/PM/2004 pada tanggal 24 September 2004, anggota komite audit disyaratkan independen dan sekurang-kurangnya ada satu orang yang memiliki di bidang akuntansi atau keuangan. Berdasarkan pedoman corporate governance, anggota komite audit harus memiliki suatu keseimbangan keterampilan dan pengalaman dengan latar belakang usaha yang luas. Setidaknya satu anggota komite audit harus pula mempunyai pengertian yang baik tentang pelaporan keuangan. Dalam penelitian ini, pengukuran latar belakang pendidikan dengan cara total komite audit yang memiliki latar belakang pendidikan 
akuntansi atau keuangan dibagi dengan komite audit yang terdapat pada perusahaan perbankan tersebut.

Berdasarkan uraian diatas, maka dapat dirumuskan beberapa hipotesis yang akan dilakukan dalam penelitian ini, yaitu :

$\mathrm{H}_{1}$ : Ada pengaruh yang signifikan antara ukuran dewan komisaris terhadap pengungkapan pengendalian internal

$\mathrm{H}_{2}$ : Ada pengaruh yang signifikan antara komposisi dewan komisaris independen terhadap pengungkapan pengendalian internal

$\mathrm{H}_{3}$ : Ada pengaruh yang signifikan antara kepemilikan manajerial terhadap pengungkapan pengendalian internal

$\mathrm{H}_{4}$ : Ada pengaruh yang signifikan antara kepemilikan institusional terhadap pengungkapan pengendalian internal $\mathrm{H}_{5}$ : Ada pengaruh yang signifikan antara ukuran komite audit terhadap pengungkapan pengendalian internal $\mathrm{H}_{6}$ : Ada pengaruh yang signifikan antara latar belakang pendidikan akuntasi atau keuangan komite audit terhadap pengungkapan pengendalian internal

\section{METODOLOGI PENELITIAN}

Sumber data yang digunakan dalam pelitian ini adalah data sekunder yang diperoleh dari laporan keuangan dan laporan tahunan yang ada di website resmi
Bursa Efek Indonesia (BEI) yaitu www.idx.co.id. Data penelitian ini diolah dengan menggunakan program Statistical Package For the Social Sciences (SPSS) versi 22. Selanjutnya dilakukan uji asumsi klasik dan pengujian hipotesis dalam penelitian ini akan diuji dengan analisis regresi linear berganda untuk mengetahui pengaruh variabel independen terhadap variabel dependen dengan tingkat keyakinan 95\%. Teknik pengujian hipotesis dalam penelitian ini adalah uji $\mathrm{F}$ (uji Simultan), Uji t (uji parsial), dan uji koefisien determinasi (Adjusted $R^{2}$ ).

\section{HASIL \& ANALISIS}

Dalam penelitian ini, perusahaan yang diteliti adalah perusahaan perbankan yang terdaftar di Bursa Efek Indonesia (BEI) pada tahun 2013-2015. Objek penelitian ini adalah variabel bebas (independen) yaitu mekanisme corporate governance yang dipresentasikan dengan ukuran dewan komisaris, komposisi dewan komisaris independen, kepemilikan manajerial, kepemilikan institusional, ukuran komite audit, dan latar belakang pendidikan akuntansi atau keuangan komite audit sedangkan pengungkapan pengendalian internal merupakan variabel terikat (dependen). 
Tabel 1

Statistik Deskriptif

\begin{tabular}{|l|r|r|r|r|r|}
\hline & $\mathrm{N}$ & Minimum & Maximum & \multicolumn{1}{c|}{ Mean } & Std. Deviation \\
\hline DISC & 90 & .52 & .96 & .7649 & .11547 \\
BSIZE & 90 & 3 & 9 & 4.72 & 1.676 \\
INDEP & 90 & .20 & .75 & .5631 & .12235 \\
MO & 90 & .00 & 28.23 & 2.7948 & 5.34860 \\
IO & 90 & 3.55 & 99.15 & 64.8015 & 28.88744 \\
ACSIZE & 90 & 3 & 8 & 4.60 & 1.397 \\
ACEDU & 90 & .25 & .67 & .4100 & .11441 \\
Valid N (listwise) & 90 & & & & \\
\hline
\end{tabular}

Sumber : pengolahan data sekunder dengan SPSS 22

Pada tabel 1 dapat dilihat bahwa nilai $\mathrm{N}$ menunjukkan banyaknya sampel yang digunakan pada penelitian ini sebanyak 90 data. Pengungkapan pengendalian internal (DISC) memiliki nilai rata - rata sebesar 0,7649 , nilai minimum sebesar 0,52 , nilai maximum sebesar 0,96 dan nilai standar deviasi sebesar 0,11547. Hal ini menunjukkan bahwa tingkat pengungkapan pengendalian internal pada perusahaan perbankan di Indonesia sudah cukup baik karena nilai rata-rata memperoleh skor lebih dari setengah poin maksimal penelitian.

Nilai rata - rata ukuran dewan komisaris (BSIZE) sebesar 4,72, nilai minimum sebesar 3, nilai maximum sebesar 9, dan nilai standar deviasi 1,676. Hal ini menunjukkan bahwa rata - rata perusahaan perbankan di Indonesia telah memenuhi peraturan yang dikeluarkan oleh Bank Indonesia yaitu memiliki dewan komisaris minimal 3 orang.
Komposisi dewan komisaris independen (INDEP) menunjukkan nilai rata-rata 0,5631, nilai minimum 0,20 , nilai maximum 0,75 , dan nilai standar deviasi 0,12235. Hal ini menunjukkan bahwa jumlah anggota dewan komisaris independen telah memenuhi Peraturan Bank Indonesia No. 8/14/2006 tentang penerapan good corporate governance yang mewajibkan perusahaan perbankan memiliki anggota komisaris independen minimal $50 \%$ dari jumlah dewan komisaris. Meski demikian, hal ini pun dapat mengindikasikan bahwa dalam menetapkan jumlah anggota dewan komisaris independen, perusahaan hanya mempertimbangkan untuk memenuhi syarat Peraturan Bank Indonesia.

Nilai rata - rata kepemilikan manajerial (MO) di perusahaan perbankan adalah sebesar 2,7948, nilai minimum sebesar 0,000052 , nilai maximum sebesar 28,23, dan nilai standar deviasi sebesar 5,34860. Hal ini menunjukkan bahwa persentase 
kepemilikan manajerial dalam perusahaan perbankan cukup rendah.

Kepemilikan institusional (IO) memiliki nilai rata-rata sebesar 64,8015 , nilai minimum sebesar 3,55, nilai maksimum sebesar 99,15, dan nilai standar deviasi sebesar 28,88744. Hal ini menunjukkan bahwa persentasi kepemilikan institusional cukup tinggi dibandingkan dengan kepemilikan manajerial.

Nilai rata - rata ukuran komite audit (ACSIZE) sebesar 4,60, nilai minimum sebesar 3, nilai maksimum sebesar 8 , dan nilai standar deviasi sebesar 1,397. Rata rata ukuran komite audit pada perusahaan perbankan telah memenuhi ketentuan Bapepam tentang jumlah minimal anggota komite audit yaitu sebanyak 3 orang.

Latar belakang pendidikan akuntansi atau keuangan komite audit (ACEDU) memiliki nilai rata - rata sebesar 0,4100, nilai minimum sebesar 0,25 , nilai maximum sebesar 0,67 , dan nilai standar deviasi sebesar 0,11441. Rata - rata latar belakang pendidikan akuntansi atau keuangan komite audit, menunjukkan bahwa kesadaran perusahaan perbankan di Indonesia masih rendah dalam memilih dan menetapkan anggota komite audit yang kompeten.

Pengujian Asumsi Klasik dilakukan untuk mengetahui apakah model regresi yang digunakan dalam melakukan penelitian ini layak digunakan atau tidak. Dalam uji asumsi klasik terdapat 4 uji yang akan dilakukan dalam penelitian ini yaitu, uji normalitas, uji multikolineritas, uji heteroskedastisitas, dan uji autokorelasi.

Tabel 2

Hasil uji asumsi klasik

\begin{tabular}{cc}
\hline Pengujian Asumsi Klasik & Hasil \\
\hline Uji Normalitas & Model regresi terdistribusi secara normal \\
Uji Multikolonieritas & Model regresi tidak terjadi multikolonieritas \\
Uji Autokorelasi & Model regresi tidak terjadi autokorelasi \\
Uji Heteroskedastisitas & Model regresi tidak terjadi heteroskedastisitas \\
\hline
\end{tabular}

Setelah semua uji asumsi klasik telah terpenuhi, maka langkah selanjutnya adalah melakukan pengujian hipotesis analisis regresi linear berganda. Dengan menggunakan program SPSS versi 22, maka didapat hasil analisis regresi linear berganda sebagai berikut : 
Tabel 3

Hasil Regresi Linear Berganda

\begin{tabular}{|c|c|c|c|c|c|c|}
\hline \multirow{2}{*}{\multicolumn{2}{|c|}{ Model }} & \multicolumn{2}{|c|}{$\begin{array}{c}\text { Unstandardized } \\
\text { Coefficients }\end{array}$} & \multirow{2}{*}{$\begin{array}{c}\text { Standardized } \\
\text { Coefficients }\end{array}$} & \multirow[b]{2}{*}{$\mathrm{t}$} & \multirow[b]{2}{*}{ Sig. } \\
\hline & & B & Std. Error & & & \\
\hline & (Constant) & .664 & .086 & & 7.692 & .000 \\
\hline & BSIZE & .017 & .008 & .253 & 2.294 & .024 \\
\hline & INDEP & .181 & .096 & .192 & 1.883 & .063 \\
\hline & MO & .005 & .002 & .234 & 2.094 & .039 \\
\hline & IO & -.001 & .000 & -.173 & -1.578 & .118 \\
\hline & ACSIZE & .012 & .008 & .150 & 1.512 & .134 \\
\hline & ACEDU & -.268 & .102 & -.265 & -2.620 & .010 \\
\hline
\end{tabular}

a. Dependent Variable: DISC

Sumber : pengolahan data sekunder dengan SPSS 22

Berdasarkan tabel 3 diatas dapat dilihat model regresi berganda adalah sebagai berikut :

$$
\mathrm{Y}=0,664+0,017 \mathrm{BSIZE}+0,181 \mathrm{INDEP}+0,005 \mathrm{MO}-0,001 \mathrm{IO}+0,012 \mathrm{ACSIZE}-
$$$$
0,268 \mathrm{ACEDU}+\varepsilon
$$

Hasil pengujian hipotesis 1 yang dilakukan secara pasial dengan menggunakan uji-t menunjukkan bahwa variabel independen ukuran dewan komisaris memiliki nilai signifikansi $0,024<\alpha(0,05)$, maka $\mathrm{H}_{1}$ diterima. Jadi secara parsial terdapat pengaruh yang signifikan antara variabel independen ukuran dewan komisaris terhadap pengungkapan pengendalian internal jika variabel independen lainnya dikontrol dengan tingkat signifikansi sebesar 5\%. Hal ini dapat membuktikan bahwa dengan adanya dewan komisaris dapat memecahkan masalah asimetri informasi. Peningkatan pengawasan dan pemantauan oleh dewan komisaris dan komite-komitenya selain mengurangi terjadinya asimetri informasi juga dapat mempengaruhi kinerja keuangan. Hasil penelitian ini sesuai dengan hasil penelitian R. Zulfikar, R. Rosiana, dan R.A.F. Nariah (2015), Leng dan Ding (2011), dan Zhou dan Chen (2010) yang mengatakan bahwa ukuran dewan komisaris berpengaruh secara signifikan terhadap pengungkapan pengendalian internal. Penelitian ini menunjukkan bahwa semakin banyak angggota dewan komisaris akan berpengaruh pada semakin tingginya pengungkapan pengendalian internal perusahaan perbankan di Indonesia. Dewan komisaris memiliki tugas untuk mengawasi kinerja manajemen dan bertindak untuk memberikan masukan kepada dewan direksi. Dewan komisaris dalam melakukan tugas pengawasannya juga memberikan jaminan transparansi yang dilakukan oleh manajemen. Oleh karena itu, ukuran dewan komisaris yang besar dapat memunculkan perpaduan 
keahlian sehingga dapat meningkatkan kualitas pengungkapan informasi yang disampaikan termasuk pengungkapan pengendalian internal

Hasil pengujian hipotesis 2 yang dilakukan secara pasial dengan menggunakan uji-t menunjukkan bahwa variabel independen komposisi komisaris independen memiliki nilai signifikansi $0,063>\alpha(0,05)$, maka $\mathrm{H}_{2}$ ditolak. Jadi secara parsial tidak terdapat pengaruh yang signifikan antara variabel independen komposisi komisaris independen terhadap pengungkapan pengendalian internal jika variabel independen lainnya dikontrol dengan tingkat signifikansi sebesar 5\%. Dengan demikian, hasil penelitian tidak berhasil membuktikan bahwa variabel independen komposisi dewan komisaris independen merupakan variabel yang relevan untuk meningkatkan pengungkapan pengendalian internal perusahaan perbankan. Hasil penelitian ini sesuai dengan hasil penelitian R. Zulfikar, R. Rosiana, dan R.A.F. Nariah (2015) yang mengatakan bahwa komposisi dewan komisaris independen tidak berpengaruh secara signifikan terhadap pengungkapan pengendalian internal. Namun, hasil penelitian ini bertolak belakang dengan penelitian yang dilakukan oleh Zhou dan Chen (2010) yang mengatakan bahwa komposisi dewan komisaris independen berpengaruh secara signifikan terhadap pengungkapan pengendalian internal. Komposisi dewan komisaris independen yang besar dalam perusahaan tersebut tidak menjamin pengungkapan pengendalian internal. Hal ini dimungkinkan bahwa pengangkatan komisaris independen hanya untuk memenuhi peraturan pemerintah saja. Fenomena di Indonesia juga menunjukkan bahwa pengangkatan komisaris independen bukan berdasarkan kompetensi dan profesionalisme namun hanya berdasarkan penghargaan atau penghormatan. Sehingga dapat dikatakan bahwa pengangkatan komisaris independen kurang mempertimbangkan integritas serta kompetensi.

Hasil pengujian hipotesis 3 yang dilakukan secara pasial dengan menggunakan uji-t menunjukkan bahwa variabel independen kepemilikan manajerial memiliki nilai signifikansi $0,039<\alpha(0,05)$, maka $\mathrm{H}_{3}$ diterima. Jadi secara parsial terdapat pengaruh yang signifikan antara variabel independen kepemilikan manajerial terhadap pengungkapan pengendalian internal jika variabel independen lainnya dikontrol dengan tingkat signifikansi sebesar 5\%. Dengan demikian, hasil penelitian yang menunjukkan koefisien positif berarti bahwa tingginya kepemilikan manajerial akan berpengaruh 
pada tingginya pengungkapan pengendalian internal perusahaan perbankan di Indonesia. Kepemilikan manajerial ini didukung oleh agency theory bahwa manajer yang memiliki saham terhadap perusahaan tentunya akan menselaraskan kepentingannya dengan kepentingan sebagai pemegang saham. Hasil penelitian ini tidak sesuai dengan hasil penelitian R. Zulfikar, R. Rosiana, dan R.A.F. Nariah (2015) yang mengatakan bahwa kepemilikan manajerial tidak berpengaruh secara signifikan terhadap pengungkapan pengendalian internal. Kepemilikan manajerial menyelaraskan kepentingan pemilik dana gen, sehingga dapat mengurangi masalah agensi. Melalui kepentingan manajerial maka tindakan oportunis manajer untuk memaksimalkan kepentingan pribadi akan berkurang dan manajer akan mengambil keputusan sesuai dengan kepentingan perusahaan karena berkaitan dengan kepentingannya sebagai pemilik, sehingga pengungkapan pengendalian internal akan semakin berkualitas.

Hasil pengujian hipotesis 4 yang dilakukan secara pasial dengan menggunakan uji-t menunjukkan bahwa variabel independen kepemilikan institusional memiliki nilai signifikansi $0,118>\alpha(0,05)$, maka $\mathrm{H}_{4}$ ditolak. Jadi secara parsial tidak terdapat pengaruh yang signifikan antara variabel independen kepemilikan institusional terhadap pengungkapan pengendalian internal jika variabel independen lainnya dikontrol dengan tingkat signifikansi sebesar 5\%. Dengan demikian, hasil penelitian tidak berhasil membuktikan bahwa variabel independen kepemilikan institusional merupakan variabel yang relevan untuk meningkatkan pengungkapan pengendalian internal perusahaan perbankan. Hal ini menunjukkan bahwa para pemegang saham institusional tidak berusaha untuk memperbaiki fungsi pengawasan terhadap perilaku manajemen dalam upaya meminimalisir masalah-masalah agensi yang mungkin akan timbul. Hasil penelitian ini sesuai dengan hasil penelitian R. Zulfikar, R. Rosiana, dan R.A.F. Nariah (2015) yang mengatakan bahwa kepemilikan institusional tidak berpengaruh secara signifikan terhadap pengungkapan pengendalian internal. Hal ini terjadi karena investor institusi tidak menggunakan haknya untuk mengawasi manajemen. Hal ini juga didukung dengan indikasi bahwa karakteristik struktur kepemilikan di Indonesia yang terkonsentrasi pada kepemilikan keluarga (Lukviarman, 2004).

Hasil pengujian hipotesis 5 yang dilakukan secara pasial dengan menggunakan uji-t menunjukkan bahwa variabel independen ukuran komite audit memiliki nilai 
signifikansi $0,134>\alpha(0,05)$, maka $\mathrm{H}_{5}$ ditolak. Jadi secara parsial tidak terdapat pengaruh yang signifikan antara variabel independen ukuran komite audit terhadap pengungkapan pengendalian internal jika variabel independen lainnya dikontrol dengan tingkat signifikansi sebesar $5 \%$. Dengan demikian, hasil penelitian tidak berhasil membuktikan bahwa variabel independen ukuran komite audit merupakan variabel yang relevan untuk meningkatkan pengungkapan pengendalian internal perusahaan perbankan. Hal ini juga tidak menunjukkan bahwa komite audit tidak melakukan pengawasan yang dapat meminimalisir terjadinya asimetri informasi. Hasil penelitian ini sesuai dengan hasil penelitian R. Zulfikar, R. Rosiana, dan R.A.F. Nariah (2015) yang mengatakan bahwa ukuran komite audit tidak berpengaruh secara signifikan terhadap pengungkapan pengendalian internal. Tetapi hasil penelitian ini tidak sesuai dengan hasil penelitian Zhou dan Chen (2010) dan Shaoqing Song (2008) yang mengatakan bahwa ukuran komite audit berpengaruh secara signifikan terhadap pengungkapan pengendalian internal. Hal ini disebabkan karena komite audit dibentuk hanya sebagai formalitas untuk memenuhi peraturan Bapepam tanpa mempertimbangkan efektivitas dan kompleksitas perusahaan. Jumlah komite audit yang besar tidak menjamin keefektivan tugasnya. Keefektivan justru lebih dipengaruhi oleh kompetensi masing-masing anggota komite audit daripada kuantitas komite audit yang ada. Hasil pengujian hipotesis 6 yang dilakukan secara pasial dengan menggunakan uji-t menunjukkan bahwa variabel independen latar belakang pendidikan akuntansi atau keuangan komite audit memiliki nilai signifikansi $0,010<\alpha(0,05)$, maka $\mathrm{H}_{6}$ diterima. Jadi secara parsial terdapat pengaruh yang signifikan antara variabel independen latar belakang pendidikan akuntansi atau keuangan komite audit terhadap pengungkapan pengendalian internal jika variabel independen lainnya dikontrol dengan tingkat signifikansi sebesar 5\%. Dengan demikian, hasil penelitian membuktikan bahwa variabel independen latar belakang pendidikan akuntansi atau keuangan komite audit merupakan variabel yang relevan untuk meningkatkan pengungkapan pengendalian internal perusahaan perbankan. Hasil penelitian ini sesuai dengan hasil penelitian R. Zulfikar, R. Rosiana, dan R.A.F. Nariah (2015) dan Leng dan Ding (2011) yang mengatakan bahwa latar belakang pendidikan akuntansi atau keuangan komite audit berpengaruh secara signifikan terhadap pengungkapan 
pengendalian internal. Dengan kompetensi maka komite audit dapat bekerja efektif meningkatkan pengendalian internal yang memiliki kekuatan untuk meningkatkan pengungkapan yang berpengaruh kepada nilai perusahaan.

Tabel 4

Hasil ANOVA

\begin{tabular}{|c|c|c|c|c|c|c|}
\hline \multicolumn{2}{|c|}{ Model } & $\begin{array}{l}\text { Sum of } \\
\text { Squares }\end{array}$ & $\mathrm{df}$ & $\begin{array}{l}\text { Mean } \\
\text { Square }\end{array}$ & $\mathrm{F}$ & Sig. \\
\hline \multirow[t]{3}{*}{1} & Regression & .245 & 6 & \multirow{3}{*}{$\begin{array}{r}.041 \\
.011\end{array}$} & \multirow[t]{3}{*}{3.598} & \multirow[t]{3}{*}{$.003^{b}$} \\
\hline & Residual & .942 & 83 & & & \\
\hline & Total & 1.187 & 89 & & & \\
\hline
\end{tabular}

a. Dependent Variable: DISC

b. Predictors: (Constant), ACEDU, BSIZE, ACSIZE, INDEP, IO, MO

Sumber : pengolahan data sekunder dengan SPSS 22

Berdasarkan tabel 4 diatas dapat dilihat bahwa nilai signifikansi yang diperoleh adalah sebesar 0,003 dimana nilai tersebut lebih lebih kecil dari 0,05. Berdasarkan hasil tersebut dapat disimpulkan bahwa model regresi dapat digunakan untuk memprediksi adanya variabel dependen pengungkapan pengendalian internal dan variabel independen yaitu ukuran dewan komisaris, komposisi komisaris independen, kepemilikan manajerial, kepemilikan institusional, ukuran komite audit, dan latar belakang pendidikan akuntansi atau keuangan komite audit secara bersama - sama berpengaruh terhadap pengungkapan pengendalian internal.

Uji koefisien determinasi (adjusted $R^{2}$ ) digunakan untuk mengukur seberapa jauh kemampuan model dalam menjelaskan variabel dependen. Pada kolom adjusted $R^{2}$ dapat diketahui berapa persentase yang dapat dijelaskan oleh variabel-variabel independen terhadap variabel dependen. Sedangkan sisanya dipengaruhi atau dijelaskan oleh variabel-variabel lain yang tidak terdapat dalam model penelitian. Hasil pengujian koefisien determinasi (adjusted $R^{2}$ ) terdapat pada tabel 5, sebagai berikut :

Tabel 5

Model Summary

\begin{tabular}{|l|r|r|r|r|}
\hline Model & $\mathrm{R}$ & R Square & Adjusted R Square & \multicolumn{2}{c|}{$\begin{array}{c}\text { Std. Error of the } \\
\text { Estimate }\end{array}$} \\
\hline 1 & $.454^{\mathrm{a}}$ & .206 & .149 & .10652 \\
\hline
\end{tabular}

a. Predictors: (Constant), ACEDU, BSIZE, ACSIZE, INDEP, IO, MO

b. Dependent Variable: DISC

Sumber : pengolahan data sekunder dengan SPSS 22 
Berdasarkan tabel 5 diatas dapat dilihat bahwa nilai koefisien determinasi sebesar 0,149. Hasil tersebut dapat dikatakan bahwa sebesar $14,9 \%$ variabel dependen yaitu pengungkapan pengendalian internal dapat dijelaskan oleh variabel independen yaitu ukuran dewan komisaris, komposisi dewan komisaris independen, kepemilikan manajerial, kepemilikan institusional, ukuran komite audit, dan latar belakang pendidikan akuntansi atau keuangan komite audit. Sedangkan sisanya $85,1 \%$ $(100 \%-14,9 \%)$ dijelaskan oleh variabel variabel lainnya yang tidak diungkapkan dalam penelitian ini.

\section{KESIMPULAN}

Berdasarkan hasil analisis dapat disimpulkan bahwa ukuran dewan komisaris, kepemilikan manajerial, dan latar belakang pendidikan akuntansi atau keuangan komite audit berpengaruh secara signifikan terhadap pengungkapan pengendalian internal. Sedangkan, komposisi komisaris independen, kepemilikan institusional, dan ukuran komite audit tidak berpengaruh secara signifikan terhadap pengungkapan pengendalian internal. Hal ini dibuktikan dengan dilakukannya uji t.

Hasil penelitian menunjukkan bahwa semakin banyak anggota dewan komisaris akan berpengaruh pada semakin tingginya pengungkapan pengendalian internal perusahaan perbankan di Indonesia. Dewan komisaris memiliki tugas untuk mengawasi kinerja manajemen dan bertindak untuk memberikan masukan kepada dewan direksi. Dewan komisaris dalam melakukan tugas pengawasannya juga memberikan jaminan transparansi yang dilakukan oleh manajemen. Oleh karena itu, ukuran dewan komisaris sangat mempengaruhi aktivitas pengendalian dan pengawasan. Jumlah dewan komisaris yang besar dapat memunculkan perpaduan keahlian sehingga dapat meningkatkan kualitas pengungkapan informasi yang disampaikan termasuk pengungkapan pengendalian internal.

Hasil penelitian tidak berhasil membuktikan bahwa variabel independen komposisi dewan komisaris independen merupakan variabel yang relevan untuk meningkatkan pengungkapan pengendalian internal perusahaan perbankan. Komposisi dewan komisaris independen yang besar dalam perusahaan tersebut tidak menjamin pengungkapan pengendalian internal. Hal ini dimungkinkan bahwa pengangkatan komisaris independen hanya untuk memnuhi peraturan dari pemerintah saja. Selain itu, terdapat juga fenomena di Indonesia bahwa pengangkatan komisaris independen bukan berdasarkan kompetensi 
dan profesionalisme namun hanya berdasarkan penghargaan atau penghormatan. Sehingga dapat dikatakan bahwa pengangkatan komisaris independen di Indonesia kurang mempertimbangkan intergritas serta kompetensi.

Hasil penelitian yang menunjukkan bahwa tingginya kepemilikan manajerial akan berpengaruh pada tingginya pengungkapan pengendalian internal perusahaan perbankan di Indonesia. Kepemilikan manajerial dapat menyeleraskan kepentingan pemilik dan agen, sehingga dapat mengurangi masalah agensi. Melalui kepemilikan manajerial maka tindakan oportunis manajer untuk memaksimalkan kepentingan pribadi akan berkurang dan manajer akan mengambil keputusan sesuai dengan kepentingan perusahaan karena berkaitan dengan kepentingannya sebagai pemilik, sehingga pengungkapan pengendalian internal akan semakin berkualitas.

Hasil penelitian tidak berhasil membuktikan bahwa variabel independen kepemilikan institusional merupakan variabel yang relevan untuk meningkatkan pengungkapan pengendalian internal perusahaan perbankan. Hal ini terjadi karena investor institusi tidak optimal menggunakan haknya untuk mengawasi manajemen. Selain itu, hal ini diindikasikan terjadi karena karakteristik struktur kepemilikan di Indonesia yang terkonsentrasi pada kepemilikan keluarga (Lukviarman, 2004).

Hasil penelitian tidak berhasil membuktikan bahwa variabel independen ukuran komite audit merupakan variabel yang relevan untuk meningkatkan pengungkapan pengendalian internal perusahaan perbankan. Hal ini disebabkan karena komite audit dibentuk hanya sebagai formalitas untuk memenuhi pertauran Bapepam tanpa mempertimbangkan efektifitas dan kompleksitas perusahaan. Penelitian ini membuktikan bahwa jumlah komite audit yang besar tidak menjamin keefektifan tugas komite audit tersebut. Keefektifan dari pengawasan oleh komite audit lebih dipengaruhi dari kompetensi masing masing anggota komite audit daripada kuantitas komite audit yang ada.

Hasil penelitian membuktikan bahwa variabel independen latar belakang pendidikan akuntansi atau keuangan komite audit merupakan variabel yang relevan untuk meningkatkan pengungkapan pengendalian internal perusahaan perbankan. Keberadaan anggota komite audit yang memiliki latar belakang pendidikan di bidang akuntansi atau keuangan dianggap lebih profesional dalam melaksanakan tugasnya. Menurut Pembanyun dan Januarti (2012) kompetensi komite audit merupakan 
karakteristik penting untuk menilai efektivitas kinerja komite audit. Komite audit yang efektif dapat meningkatkan pengendalian internal yang memiliki kekuatan untuk meningkatkan pengungkapan yang berpengaruh dengan nilai perusahaan.

SARAN. Untuk penelitian selanjutnya diharapkan dapat memperluas periode pengamatan dan populasi perusahaan yang dijadikan sampel. Ini diperlukan agar hasil penelitian dapat diuji konsistensi dan generalisasinya serta untuk penelitian selanjutnya, sebaiknya menggunakan variabel independen yang tidak hanya terbatas pada corporate governance saja. Misalnya melibatkan jumlah pertemuan dewan komisaris, karena Surat Edaran Bank Indonesia nomor 5/22/DPNP tahun 2003 menyatakan bahwa dewan komisaris harus membahas efektivitas sistem pengendalian internal perusahaan minimal satu kali pertemuan.

\section{DAFTAR PUSTAKA}

Agyei dan Mensah . (2016) . Internal control information disclosure and corporate governance: evidence from an emerging market", Corporate Governance, $\quad$ Vol. 16 http://dx.doi.org/10.1108/CG-102015-0136
Boediono,Gideon. (2005). Kualitas Laba: Studi Pengaruh Mekanisme Corporate Governance dan Dampak Manajemen Laba dengan Menggunakan Analisis Jalur. Simposium Nasional Akuntansi (SNA) VIII Solo

Committee of Sponsoring Organizations of The Treadway Commission (COSO). (2013). Internal Control - Integrated Framework. http://www.coso.org/

Dhaliwal, Hogan, Trezevant, dan Wilkins. (2011). Internal Control Disclosures, Monitoring,

and the Cost of Debt. The Accounting Review. Vol 86, No. 4

Fidyati, Nisa. (2004). Pengaruh Mekanisme Corporate Governance terhadap Earnings Management pada Perusahaan Seasoned Equity Offering (SEO). Jurnal Ekonomi, Manajemen dan Akuntansi. Vol.2

Forum for Corporation Governance in Indonesia. (2000). Corporate Governance: Tata Kelola Perusahaan,Jakarta: FCGI

Ghozali, Imam. (2012).”Aplikasi Analisis Multivariate dengan Program IBM SPSS 20".

Semarang: Badan Penerbit Undip.

Jensen,M.C. and Meckling, W.H. (1976). Theory of The Firm : Managerial Behavior, Agency Costs and Ownership Structure. Journal of Financial Economics. Oktober. Vol. 3, No. 4

Juniarti dan A.A. Sentosa. (2009) Pengaruh Good Corporate Governance, Voluntary Disclosure terhadap Biaya Utang (Cost of Debt). Jurnal Akuntansi Keuangan, Vol.11 
Komite Nasioal Kebijakan Governance. (2006). Pedoman umum Good Corporate Governance

L.R. Chen and S.G. Zhou. (2010). "Empirical Research on the Efficiency of Internal Control: Based on the Empirical Evidence from the Perspective of Auditor Changing". Contemporary Finance and Economics, Vol. 10

Leng ,Ding. (2011). Internal Control Disclosure and Corporate Governance: Empirical Research from Chinese Listed Companies. doi:10.4236/ti.2011.24029

Linda dan Febrianty. (2010). Kinerja Perusahaan dalam Perspektif Agency Theory dan Signalling Theory. Jurnal Ekonomi dan Bisnis, Vol 9 No. 2

Lukviarman, N. (2004). Ownership

Structure and Firm Performance: the case of Indonesia. Doctoral Thesis of Curtin University of Technology. Australia.

Mehran, H. (1992). "Executive Incentives Plans, Corporate Control, and Capital Structure". Journal of Financial and Quantitative Analysis

Nasution, Marihot dan Doddy Setiawan. (2007). Pengaruh Corporate Governance Terhadap Manajemen Laba di Industri Perbankan Indonesia. SNA X Makasar

Patelli,L \& Prencipe,A. (2007). The Relationship between Voluntary Disclosure and Independent Directors in the Presence of a Dominant Shareholder. European Accounting Review
Pembayun, G dan Januarti, I. (2012).

Pengaruh Karakteristik Komite Audit

Terhadap Financial Distress. Vol 1,

Nomor 1, Halaman 6.

Peraturan Bank Indonesia Nomor: 11/25/PBI/2009. Tentang penerapan manajemen risiko

bagi bank umum.

Peraturan Bank Indonesia nomor 14/14/PBI/2012. Tentang Transparansi dan Publikasi Laporan Bank.

Rachmawati dan Triatmoko. (2007). "Analisis Faktor-Faktor yang Mempengaruhi Kualitas Laba dan Nilai Perusahaan". Simposium Nasional Akuntansi X Makassar

S. Q. Song and Y. Zhang. (2008). "Analysis of the Affecting Factors of Internal Control Disclosure from the Perspective of Corporate Governance". Communication of Finance and Accounting, Vol.10

Scott, R.W. 2000. Financial Accounting Theory, 2nd Ed. Prentice Hall, New Jersey

Sedarmayanti. (2007). Good Governance dan Good Corporate Governance, Bandung: Mandar Maju

Subramaniam, N Mc Manus, L and Zhang, J. (2009). Corporate governance, firm characteristic and risk management committee formation in Australia companies. Managerial auditing journal. 24 (4): 316 - 339

Suhardjanto ,Dewi ,Rahmawati ,dan Firazonia. (2012). Peran Corporate Governace dalam praktik Risk Disclosure pada perbankan Indonesia. Jurnal Akuntansi \& Auditing. Vol 9 ,No.1 November 2012 
Surat Edaran Bank Indonesia nomor 14/35/DPNP/2012 tentang Laporan Tahunan Bank Umum dan laporan Tahunan Tertentu yang Disampaikan kepada Bank Indonesia.

Surat Edaran Bank Indonesia nomor 5/22/DPNP/2003. Pedoman Standar Sistem Pengendalian Intern bagi Bank Umum

Standar Profesional Akuntan Publik. (2001). 319 paragraf 2
Zulfikar, Rosiana , dan Nariah . 2015. Corporate Governance dan Pengungkapan Pengendalian Intern. Jurnal Akuntansi. Vol 1, No. 2 Januari 2015

http://grundelanbankcentury.wordpress.co m ,2010

http://www.tempointeraktif.com ,2009 